\title{
Model of China-US Relationship After COVID Pandemic
}

\author{
Yutao Wang
}

MSAF Student Pepperdine University Malibu California, USA

Karl.yutao.wang@foxmail.com

\begin{abstract}
After the US-China Trade War starting from 2017, the conflicts in terms of both democracy and finance have been walloping the economy of two countries. Starting from the explosion of COVID-19, the recession effect brought by the Trade War was deepening. This new unusual pattern between China and the US then became the mainstream of the contemporary world. From Foot R. (1995), it is exactly the time that she predicted that "the United States clearly gained in terms of its structural power as a result of the normalization of ties and the introduction of reform policies in China"[1].

This paper analyzes the economic behavior and gives a prediction of further US-China relationships by establishing an economic model, standing from the investors' perspective. A previous result based on the standard open economy model is introduced in the establishment. The methodology takes the advantage of linear regression, hypothesis test, game theory and other theoretical results to yield a numerical conclusion. And the key question includes: How close is it between China and US economy; what would China and the US do based on a static game; and what should we investors do in this situation. The conclusion lies on the prediction of only economic analysis but irrelevant to democracy or other policies, and this paper would indicate a direction for international markets, especially on the FOREX market
\end{abstract}

Keywords: International Trade, US-China Trade War, quantitative analysis, game theory.

\section{INTRODUCTION}

In my previous paper: Past, present, and future: Research on the Influence of International Competition and Collaboration Relationship between US and China (2021), roughly reviewed the China-US relationships starting from the establishment of the People Republic's of China(PRC) in 1949. In the second section I simulated a simple economy model via a purely theoretical method based on the standard open two-country economic model, obtaining the intertemporal budget constraint (IBC) and natural log utility function, where $\mathrm{Y}$ stands for output, $\mathrm{C}$ stands for consumption, $\mathrm{G}$ stands for government expenditure, TB stands for trade balance between China and US, and all in terms of discrete year $t$ and $t+1[2]$ :

$$
\begin{aligned}
& C_{t}+G_{t}+\frac{C_{t+1}+G_{t+1}}{1+r}=Y_{t}+\frac{Y_{t+1}}{1+r} \\
& \max _{C_{t}, C_{t+1}} U=\ln C_{t}+\ln C_{t+1}
\end{aligned}
$$

By transformation the paper afterward yielded that:

$$
T B_{t}^{C N}+T B_{t}^{U S}=0 \Rightarrow r=\frac{Y_{t+1}^{U S}-Y_{t+1}^{C N}-\Delta G_{t+1}}{Y_{t}^{U S}-Y_{t}^{C N}-\Delta G_{t}}-1
$$

However, to simplify this formula, the paper made an unscientific assumption here: $Y^{U S}-Y^{C N}=(\alpha+1) \bullet \Delta G+k \quad$ where $\quad \Delta G=G^{U S}-G^{C N} \quad$ In general, to assume this linear relationship, historical data and regression analysis is required. Hence, to strengthen my previous result, this paper would put the theory to the numerical test. Meanwhile, considering the marginal growth rate of the government spending difference, proportion to the GDP growth rate gap in this two-country model, the exact value of $\alpha+1$ is the key determinant of the sign of formula then changing the final conclusion: 


$$
\begin{aligned}
& -\frac{M r_{\Delta G_{t}}}{M r_{\Delta G_{t+1}}}=-\frac{\partial r / \partial \Delta G_{t}}{\partial r / \partial \Delta G_{t+1}}=-\frac{\left(\alpha \bullet \Delta G_{t+1}+k\right) \bullet \alpha /\left(\alpha \bullet \Delta G_{t}+k\right)^{2}}{\alpha /\left(\alpha \bullet \Delta G_{t}+k\right)} \\
& =-\frac{\alpha \bullet \Delta G_{t+1}+k}{\alpha \bullet \Delta G_{t}+k}
\end{aligned}
$$

\section{Data Analysis}

\subsection{Basic Formula}

To estimate the relationship between the output difference and government spending difference, I applied a simple linear regression for those two sets of data gathering from the official website. Considering that China was not re-open and reformed to the international countries until 1978, the selection of a valid period would be better to be restricted after that specific time, since the relationship would be irrelevant if there is no connection between China and the US. Hence, I took 1982 to 2019 as the projected duration for analysis, for which the scatter plot is showing a strong positive relationship (Exhibit 1), and the relation function is given as:

$$
Y^{U S}-Y^{C N}=2.4141 \bullet \Delta G+1321.37
$$

Based on the illustration, we could obtain a preliminary conclusion of the correlation between those two variables. However, to evaluate the significance and reliability of the conclusion, we also need to make a hypothesis test for the slope $\alpha+1$. Hence, what I found was that the test statistic is 15.98 , giving a $p$-value of 0.000 , which represents an extremely significant correlation (Form 1.)

Applying the relation function to the marginal growth rate of the government spending difference, we would have the exact formula as:

$-\frac{M r_{\Delta G_{t}}}{M r_{\Delta G_{t+1}}}=-\frac{\partial r / \partial \Delta G_{t}}{\partial r / \partial \Delta G_{t+1}}=-\frac{\left(\alpha \bullet \Delta G_{t+1}+k\right) \bullet \alpha /\left(\alpha \bullet \Delta G_{t}+k\right)^{2}}{\alpha /\left(\alpha \bullet \Delta G_{t}+k\right)}$

$=-\frac{\alpha \bullet \Delta G_{t+1}+k}{\alpha \bullet \Delta G_{t}+k}=-\frac{1.4141 \bullet \Delta G_{t+1}+1321.37}{1.4141 \bullet \Delta G_{t}+1321.37}$

Figure 1: Scatter Plot between GDP difference(y) and government spending difference(x) from 1982 to 2019

\begin{tabular}{|c|c|c|c|c|}
\hline \multicolumn{3}{|c|}{ Significance Test for Slope } & & \\
\hline \multirow{2}{*}{ Test Stat } & 15.98 & & & \\
\hline & Null Hypothesis & \multicolumn{2}{|c|}{ Alternatives } & $p$-value \\
\hline$H o: b 1=$ & 0 & $\begin{array}{l}\text { Ha: } \\
\text { b1 } \\
\text { not } \\
=\end{array}$ & 0 & 0.0000 \\
\hline
\end{tabular}

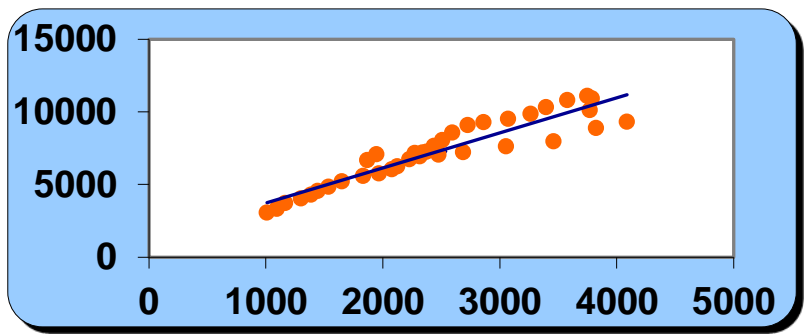

Table 1: Hypothesis test for the slope in Exhibit 1

\subsection{Adjustment}

Through the basic result, there is a significantly positive relationship between the GDP gap and government spending difference. However, the final equation should be further adjusted since there are two distinct simulation lines in the scatter plot (Exhibit 1), which intersect with each other around the level of $\$ 2400$ million as a government spending difference.

Moreover, regarding the original data (Appendix I, II), it is obvious that the disparities have experienced a turning point, and the relationship pattern seems to be combined by two different trends, regardless of the variable type, which was around 2008, the well-known Financial crisis. After that specific year, we may interpret that China, as an individual economy entity, has been catching up with the US, and the economic gap between China and the US has been approaching zero at a different speed than before, also descending the distance of government expenditure. Hence, we should treat pre-crisis and post-crisis as two different stages in terms of correlation. To revise the model and strengthen its effectiveness, it is necessary to ignore previous indicators but extract valid data after 2008. However, since the lack of annual numbers, I apply the quarter data in alternative instead to acquire higher validity and accuracy (Appendix III, IV). By simple regression, we have yielded the relationship equation as:

$$
Y^{U S}-Y^{C N}=-0.0175 \bullet \Delta G+1929.03
$$

However, it is apparent on the scatter plot that there are four outliers among our database, which directly contributed to the extremely large p-value of 0.9285 , saying we fail to reject the null hypothesis and the slope -0.0175 is highly unreliable. Hence, to revise the model, it is necessary to remove those four data points. Checking the corresponding time, we found that all four outliers are after the explosion of COVID-19, hence it is reasonable to have several abnormal numbers.

Figure 2: Scatter Plot between GDP difference(y) and government spending difference( $\mathrm{x}$ ) from 2008 to 2021 


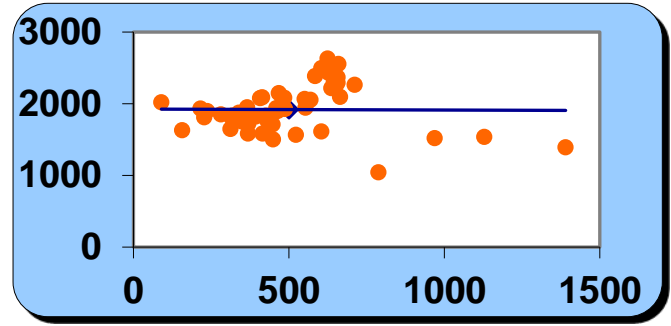

Table 2: Hypothesis test for the slope in Exhibit

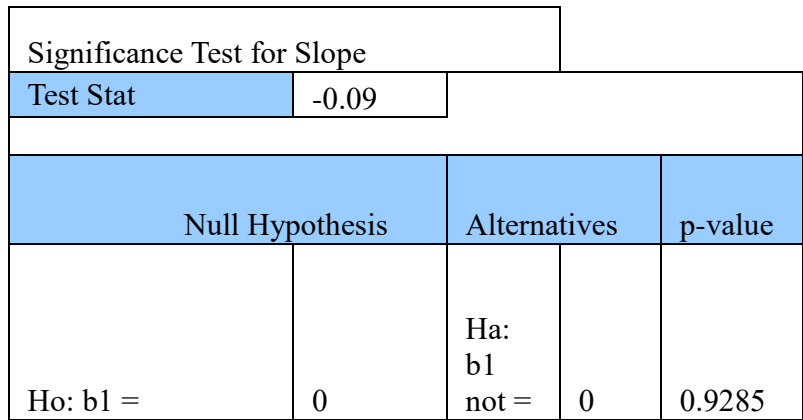

After the further adjustment, the final equation is;

$$
Y^{U S}-Y^{C N}=1.1495 \bullet \Delta G+1444.47(8)
$$

With regard to the relationship formula, we have a perfect test statistic equal to 5.38, giving us a p-value less than 0.0001 . Therefore, we may interpret that there is a significant and positive relationship between GDP difference and the government spending difference. Meanwhile, it is easy to see that both the gaps are shrinking. To testify the moving trend of the difference, this model utilized both statistical and theoretical methods to verify the decrease prediction.

Figure 3: Scatter Plot between GDP difference(y) and government spending difference $(\mathrm{x})$ from 2008 to 2021 despite outliers

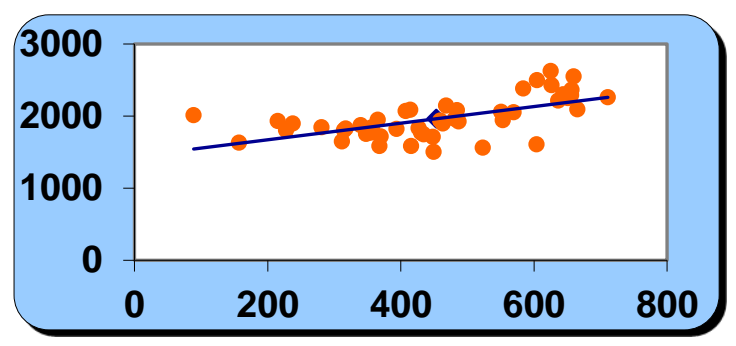

Table 3: Hypothesis test for the slope in Exhibit 3

\begin{tabular}{|c|c|c|c|c|}
\hline \multicolumn{5}{|c|}{ Significance Test for Slope } \\
\hline Test Stat & 5.38 & & & \\
\hline \multicolumn{2}{|c|}{ Null Hypothesis } & \multicolumn{2}{|c|}{ Alternatives } & p-value \\
\hline Ho: $b 1=$ & 0 & $\begin{array}{l}\text { Ha: } \\
\text { b1 } \\
\text { not }=\end{array}$ & 0 & 0.0000 \\
\hline
\end{tabular}

Numerically, since the data time is quoted as a quarter in this model, we note the variable time by $\mathrm{T}$ as a quarter. Then we apply the regression again to check if time has a strong influence on the government spending gap. Noticing that the GDP gap could be almost explained by the government expenditure difference, we do not need to repeat this translation to it once more.

Figure 4: Scatter Plot between government spending difference(y) and time(x)

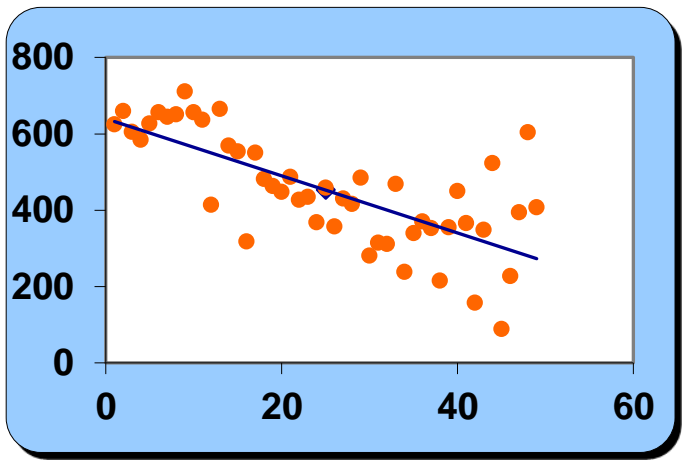

Table 4: Hypothesis test for the slope in Exhibit 4

\begin{tabular}{|c|c|c|c|c|}
\hline \multicolumn{3}{|c|}{ Significance Test for Slope } & & \\
\hline Test Stat & -7.11 & & & \\
\hline \multicolumn{2}{|c|}{ Hypothesis } & \multicolumn{2}{|c|}{ Alternatives } & $\mathrm{p}$-value \\
\hline Ho: b1 = & 0 & $\begin{array}{l}\text { Ha: } b 1 \\
\text { not }=\end{array}$ & 0 & 0.0000 \\
\hline
\end{tabular}

Based on the hypothesis test, it is obvious that the relationship is critical and obvious because of a large test statistics, in which the equation is:

$$
\Delta G=-7.4723 \bullet T+639.75
$$

However, even though this slope is significant, we may witness that on the scatter plot, the shape is becoming flared with the time going. This unusual pattern could be explained by the arising of the Trade war between China and the US, which was explained in my previous paper, Research on the Influence of International Competition and Collaboration Relationship between US and China (Wang, 2021).

Theoretically, similar to the operations above, we continue to apply this new trend line into the previous marginal growth rate function of the government spending difference, we would have the exact formula as:

$$
\begin{aligned}
& -\frac{M r_{\Delta G_{t}}}{M r_{\Delta G_{t+1}}}=-\frac{\partial r / \partial \Delta G_{t}}{\partial r / \partial \Delta G_{t+1}}=-\frac{\left(\alpha \bullet \Delta G_{t+1}+k\right) \bullet \alpha /\left(\alpha \bullet \Delta G_{t}+k\right)^{2}}{\alpha /\left(\alpha \bullet \Delta G_{t}+k\right)} \\
& =-\frac{\alpha \bullet \Delta G_{t+1}+k}{\alpha \bullet \Delta G_{t}+k}=-\frac{0.1495 \bullet \Delta G_{t+1}+1444.47}{0.1495 \bullet \Delta G_{t}+1444.47}
\end{aligned}
$$

Regardless of the exact number, what the formula stated above indicates that: whenever $\Delta G=G^{U S}-G^{C N}$ is positive, the growth rate of government spending difference index will be negative in the next time spot, saying the next quarter. After the gap gradually decreases to zero, the pattern would 
possibly maintain when China exceeds the US, until the denominator becomes negative or other shocking international events break out, meaning this overtaking tendency could sustain till China government spending exceeds the US's by $\$ 9662$ billion in a single quarter. Meanwhile, considering the relationship function between GDP gap and Government expenditure gap, we also know that the GDP gap would also shrink according to the time, saying that the Chinese GDP would exceed US GDP in some days, by which the currency value would represent the currency value, which is the most attracting factor for our FOREX investors.

Besides, there was one interesting fact that the GDP rebound happened in 2007, one year before the financial crisis, while the Chinese government spending overtook in 2009. Even though the time was not perfectly corresponding to each other, it is intuitively explainable. Currently, the basis of the Subprime Crisis is apparently about mortgage-backed securities. The multiple transactions of debt tremendously reduced the liquidity, further raised the risk, and this lack of solvency and long turnover period dramatically stopped cash flow in quantities of financial institutions like banks. Hence, one year before the bankruptcy declares, the market inefficiency was already pushed to an incredibly high extent, which contributed to the sharp decline of US GDP in 2007, also the turning point of the GDP gap. However, government spending is the lagging index that would respond later, which represented as the change in 2009.

\section{MODEL}

Based on the formula of relative purchasing power parity (RPPP), we may found that the exact depreciation or appreciation of each country is not only decided by the GDP growth rate:

$e_{\frac{U S}{C N}}=\pi_{U S}-\pi_{C N}=\left(m_{U S}-y_{U S}\right)-\left(m_{C N}-y_{C N}\right)=m_{U S}-m_{C N}-\left(y_{U S}-y_{C N}\right)$

Where e represents the depreciation rate, pi represents the inflation rate, $\mathrm{m}$ represents the money growth rate, and y represents the nominal GDP growth rate.

Noticing that there is a term $y_{U S}-y_{C N}$ in the formula, we know it refers to the GDP growth rate difference, but not equivalent to the GDP difference growth rate. Theoretically speaking, it is explained as:

$$
y_{U S}-y_{C N}=\frac{\Delta Y^{U S}}{Y_{t}^{U S}}-\frac{\Delta Y^{C N}}{Y_{t}^{C N}} \neq \frac{\Delta\left(Y^{U S}-Y^{C N}\right)}{Y_{t}^{U S}-Y_{t}^{C N}}
$$

Hence, we go back to the original data for the estimation of GDP growth rate over the period from 2008 to 2020 (despite the numbers during COVID) and to check the average number of both US and China GDP, which are $0.792 \%$ and $3.248 \%$, respectively. Hence, after the pandemic, we may assume the GDP growth rate gap is around $2.456 \%$, giving that:

$$
e_{\frac{U S}{C N}}=m_{U S}-m_{C N}+2.456 \%
$$

To predict how the exchange rate would change, another determinant other than GDP is the money growth rate, which specifically refers to the M2 money supply, a manipulative factor normally controlled by the central bank of each government. Regardless of the pandemic and trade war period between 2017 to 2021, the Chinese M2 money supply growth rate is around $12.5 \%$, while this number is approximately $6 \%$ for the US. Therefore, by estimation, the depreciation rate of USD in terms of CNY is about to be $-4 \%$ per quarter. In the contrast, US has been appreciating with a ratio of $4 \%$ every quarter compared to $\mathrm{CNY}$ in stable times, which perfectly fits the trends from 2014 to 2017. However, before 2014, the world has just suffered from the global subprime crisis in 2008, in which China has a much more outstanding performance among all countries, leading to a huge disparity between Chinese GDP growth rate compared to others, so the depreciation rate above was maintained at a moderate positive level.

Under this special circumstance, both China and the US have in general three different types of decisions: contradictionary, expansionary monetary policy, and keep the previous certain level. Considering that the M2 money supply growth was high as to be $25 \%$ during pandemic and earlier financial crisis cases, it is reasonable to set our estimation of expansionary monetary policy with a $12 \%$ growth for the US, and $18.5 \%$ for China, since those numbers were achieved before under the fastest developing ages. Meanwhile, there is a critical point that the governments are willing to make currency depreciates although, citizens are not satisfied with the overly weak money, since people are looking forward to a higher purchasing power then live a better life. As for the contradictionary monetary policy, we could set both numbers to $1 \%$. Therefore, our payoff matrix between China and the US in terms of depreciation rate $\frac{e_{U S}}{C N}, \frac{e_{C N}}{U S}$ would be given as:

Table 5. Payoff Matrix

\begin{tabular}{|l|l|l|l|}
\hline ChinalUS & $\begin{array}{l}\text { Contradictiona } \\
\text { ry(1\%) }\end{array}$ & $\begin{array}{l}\text { Maintain } \\
(6 \%)\end{array}$ & $\begin{array}{l}\text { Expansionary } \\
(12 \%)\end{array}$ \\
\hline Contradictiona & $-2.456 \%$, & $-7.456 \%$, & $-13.456 \%$, \\
ry(1\%) & $2.456 \%$ & $7.456 \%$ & $13.456 \%$ \\
\hline Maintain(12.5 & $9.044 \%$, & $4.044 \%$, & $-1.956 \%$, \\
$\%)$ & $-9.044 \%$ & $-4.044 \%$ & $1.956 \%$ \\
\hline Expansionary( & $15.044 \%$, & $10.044 \%$, & $4.044 \%$, \\
$18.5 \%)$ & $-15.044 \%$ & -10.044 & $-4.044 \%$ \\
& & $\%$ & \\
\hline
\end{tabular}

In the simple model consisted of only two countries, 
saying US and China here, knowing that the relative currency depreciation is always more favorable to countries under ordinary situations for the reason that depreciation would bring higher competitiveness of domestic goods, the US would like to make ${ }^{\frac{e_{U S}}{C N}}$ as high as it could, while China takes the opposite position,

pushing $\frac{e_{C N}}{U S}$ up as much. Hence, considering the previous payoff matrix, it is obvious that the Nash Equilibrium is that both China and the US would implement expansionary monetary policy for currency depreciation.

To achieve this, the US would take an expansionary monetary policy to acquire a higher depreciation index, while China would also issue more currency to lower RMB's value, despite diplomatic issues. Based on the previous analysis, we know China will have a higher GDP growth rate, which gives us a great residual of $2.456 \%$. Meanwhile, it is apparent that the Chinese money supply growth rate exceeds the US index for far more than this number. Hence, based on the depreciation rate equation, we may assume that after the COVID pandemic, the USD would still appreciate in terms of $\mathrm{CNY}$ with $4 \%$ per quarter, or another moderate speed in the future.

Before the general conclusion, since the methodology of this paper follows a simple two-country model, it would be biased for the further international trading analysis. According to Chudik, A. and his research members (2020), they played a thorough examination and complicated interior model within each countries or regions, including quantities of discrete indices like GDP, long-term interest rate, the logarithm of the real exchange rate as the dependent factors. As for the result, they estimated that China's GDP growth rate would be approximately lied in the range between $4.8 \%$ and $10.3 \%$, with the median of $7.9 \%$. However, it was shown that in the first quarter, China's economy was boosted with an eye-popping $18.3 \%$. Meanwhile, their prediction to the US gave a 90 percentile number of $6.4 \%$, perfectly matching the real GDP growth rate of the US in Q1 coincidentally, which could also be explained as an unexpected recovery from the pandemic[3]. Even though their estimation somewhat undervalued the potential of the global economy, but this result indeed conformed to my $6 \%$ estimation GDP growth difference between China-US.

\section{CONCLUSION}

Firstly, when it comes to the 'post-COVID' times, it is necessary to figure out the exact time this terminology indicating. Fortunately, China currently has already passed the pandemic stage. But similar to the huge stimulus package of 4 trillion RMB in the 2008
Financial Crisis, the Chinese government endowed approximately another 4 trillion RMB, including numerous tax and interest cuts. However, those monetary policies brought quantities issues in the long-term, such as sharp depreciation and overcapacity. According to the exchange rate chart between USD and CNY, this deterioration trend did not stop until 2014, indicating a 6-year recovering period. Hence, it is probably that the side effect brought from over-investment would be slowly relieved till 2026 . Same to the US, since the US society is not fully recovered from the pandemic, it is reasonable to believe that it takes longer for the US to return on track. Hence, when it refers to 'post-COVID' times, it should be no earlier than 2025. All days before this specific point would be somewhat slightly off the track, and economic principles may be different.

Meanwhile, although China and the US had signed Phase I deal in Jan 2020 to release the financial burden from trade war under severe COVID occasion. From the Kaj M. (2020), we know that US-China Economic and Security Review Commission, as one of the authorities determining bilateral relationship, declared in their report that Congress should still restrict and control the trading between China, especially export and import. Also, they emphasized the significance of crude oil, so it is foreseeable that the 'post-COVID' times would be followed by the continuing intense trading conflict[4].

As a retailed investor in the FOREX market, we may follow the prediction in the model that USD may easily appreciate compared to China RMB. Hence, since this paper is a simple analysis based on transparent materials without any intervention from political or diplomatic factors, there could be a large amount of investors going to invest in the money market in the US, saying to purchase USD as a foreign reserve. What is worse is that this huge demand of the US dollar from global investors would further increase the value of USD. On the other hand, the high GDP growth of China would also attract foreign investments to devote into the capital market, which further increases the domestic production, and then makes China RMB further depreciates.

As for the model, there are still spaces for improvement. Firstly, there was no complete quarterly data for government spending but monthly data available, especially for China. Therefore, in the adjusted scatter plot, I could only estimate the missing numbers using the multiple of some adjacent data. However, as we know, there exists a seasonal disparity between different quarters in terms of GDP because of agriculture or tourism, and also government expenditure would differ based on situations. Even the model chose to estimate some of input data, as we could see in the hypothesis test, there is no such great influence on the final equation and the significance of the slope. 
Appendix I. Historical GDP gap

\begin{tabular}{|c|c|c|c|c|c|c|}
\hline China & RMB & US Dollar & US & & & $\mathrm{Yu}-\mathrm{Y}_{\mathrm{cm}}$ \\
\hline 2019 & $99,086.50$ & $14,363.48$ & 2019 & $\Delta_{21,439.00}$ & $\mathbf{x}$ & 7075.52 \\
\hline 2018 & $91,928.11$ & $13,891.88$ & 2018 & $20,580.20$ & $x$ & 6688.32 \\
\hline 2017 & $83,203.59$ & $12,323.17$ & 2017 & $\Delta_{19,519.40}$ & $\mathbf{y}$ & 7196.23 \\
\hline 2016 & $74,639.51$ & $11,237.00$ & 2016 & $\Delta_{18,715.00}$ & $x$ & 7478 \\
\hline 2015 & $68,885.82$ & $11,059.95$ & 2015 & $\mathbf{A}_{18,224.80}$ & 1 & 7164.85 \\
\hline 2014 & $64,356.31$ & $10,476.71$ & 2014 & $\Delta 17,521.30$ & $\mathbf{y}$ & 7044.59 \\
\hline 2013 & $59,296.32$ & $9,574.42$ & 2013 & $\Delta_{16,784.90}$ & I & 7210.48 \\
\hline 2012 & $53,858.00$ & $8,531.96$ & 2012 & $\mathbf{A}_{16,155.30}$ & $\mathbf{y}$ & 7623.34 \\
\hline 2011 & $48,794.02$ & $7,554.66$ & 2011 & $\Delta_{15,517.90}$ & $\mathbf{x}$ & 7963.24 \\
\hline 2010 & $41,211.93$ & $6,087.88$ & 2010 & $\Delta_{14,964.40}$ & $\mathbf{y}$ & 8876.52 \\
\hline 2009 & $34,851.77$ & $5,102.00$ & 2009 & $14,418.70$ & I & 9316.7 \\
\hline 2008 & $31,924.46$ & $4,596.69$ & 2008 & $\Delta_{14,718,60}$ & $y$ & 10121.91 \\
\hline 2007 & $27,009.23$ & $3,551.98$ & 2007 & ${ }_{14,477.60}$ & 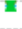 & 10925.62 \\
\hline 2006 & $21,943.85$ & $2,752.68$ & 2006 & $\Delta_{13,855.90}$ & $\mathbf{x}$ & 11103.22 \\
\hline 2005 & $18,731.89$ & $2,286.69$ & 2005 & $\Delta_{13,093.70}$ & I & 10807.01 \\
\hline 2004 & $16,184.02$ & $1,955.35$ & 2004 & $A_{12,274.90}$ & $\mathbf{x}$ & 10319.55 \\
\hline 2003 & $13,742.20$ & $1,660.29$ & 2003 & $\Delta_{11,510.70}$ & I & 9850.41 \\
\hline 2002 & $12,171.74$ & $1,470.55$ & 2002 & $\Delta 10,977.50$ & $\mathbf{y}$ & 9506.95 \\
\hline 2001 & $11,086.31$ & $1,339.41$ & 2001 & $\mathbf{A}_{10,621.90}$ & I & 9282.49 \\
\hline 2000 & $10,028.01$ & $1,211.35$ & 2000 & $A_{10,284.80}$ & $\mathbf{y}$ & 9073.45 \\
\hline 1999 & $9,056.44$ & $1,094.00$ & 1999 & $9,660.60$ & $\mathbf{x}$ & 8566.6 \\
\hline 1998 & $8,519.55$ & $1,029.04$ & 1998 & $\Delta 9,089.20$ & $\mathbf{x}$ & 8060.16 \\
\hline 1997 & $7,971.50$ & 961.6 & 1997 & $8,608.50$ & I & 7646.9 \\
\hline 1996 & $7,181.36$ & 863.75 & 1996 & $8,100.10$ & $\mathbf{x}$ & 7236.35 \\
\hline 1995 & $6,133.99$ & 734.52 & 1995 & $7,664.10$ & $\mathbf{z}$ & 6929.58 \\
\hline 1994 & $4,863.75$ & 564.33 & 1994 & $7,308.80$ & $\mathbf{Y}$ & 6744.47 \\
\hline 1993 & $3,567.32$ & 619.11 & 1993 & $6,878.70$ & De & 6259.59 \\
\hline 1992 & $2,719.45$ & 493.14 & 1992 & ${ }^{4} 6,539.30$ & I & 6046.16 \\
\hline 1991 & $2,200.56$ & 413.38 & 1991 & 6,174.10 & 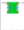 & 5760.72 \\
\hline 1990 & $1,887.29$ & 394.57 & 1990 & ${ }_{5,979.60}$ & 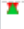 & 5585.03 \\
\hline 1989 & $1,717.97$ & 456.29 & 1989 & $5,657.70$ & I & 5201.41 \\
\hline
\end{tabular}

Appendix II. Historical Government Expenditure gap

\begin{tabular}{|c|c|c|c|c|c|c|}
\hline us & Billion $\$$ & China & Milli on $\$$ & & Billion $\$$ & Gus-Ger \\
\hline 2019 & $6,837.40$ & 2019 & $4,892,101.00$ & 0.001 & 4892.1 & 1945.3 \\
\hline 2018 & $6,425.40$ & 2018 & $4,555,845.90$ & & 4555.8 & 1869.6 \\
\hline 2017 & $6,220.90$ & 2017 & $3,883,006.30$ & & 3883 & 2337.9 \\
\hline 2016 & $6,017.80$ & 2016 & $3,584,458.00$ & & 3584.5 & 2433.3 \\
\hline 2015 & $5,785.20$ & 2015 & $3,512,073.90$ & & 3512.1 & 2273.1 \\
\hline 2014 & $5,529.60$ & 2014 & $3,050,518.80$ & & 3050.5 & 2479.1 \\
\hline 2013 & $5,437.50$ & 2013 & $2,749,260.60$ & & 2749.3 & 2688.2 \\
\hline 2012 & $5,457.00$ & 2012 & $2,403,102.60$ & & 2403.1 & 3053.9 \\
\hline 2011 & $5,492.30$ & 2011 & $2,032,256.90$ & & 2032.3 & 3460 \\
\hline 2010 & $5,337.20$ & 2010 & $1,512,890.40$ & & 1512.9 & 3824.3 \\
\hline 2009 & $5,395.00$ & 2009 & $1,306,984.60$ & & 1307 & 4088 \\
\hline 2008 & $4,803.70$ & 2008 & $1, \infty 31,214,20$ & & 1031.2 & 3772.5 \\
\hline 2007 & $4,433.20$ & 2007 & $645,325.30$ & & 645.3 & 3787.9 \\
\hline 2006 & $4,256.20$ & 2006 & $505,046.10$ & & 505 & 3751.2 \\
\hline 2005 & $3,998.70$ & 2005 & $418,102.70$ & & 418.1 & 3580.6 \\
\hline 2004 & $3,745.50$ & 2004 & 348 , 品1. 90 & & 348.6 & 3396.9 \\
\hline 2003 & $3,565.80$ & 2003 & $302,115.00$ & & 302.1 & 3263.7 \\
\hline 2002 & $3,342.10$ & 2002 & $270,856.80$ & & 270.9 & 3071.2 \\
\hline 2001 & $3,095.30$ & 2001 & $232,580.50$ & & 232.6 & 2862.7 \\
\hline 2000 & $2,921.90$ & 2000 & $196,028.30$ & & 196 & 2725.9 \\
\hline 1999 & $2,760.00$ & 1999 & $163,364.00$ & & 163.4 & 2596 . \\
\hline 1998 & $2,641.90$ & 1998 & $130,429.20$ & & 130.4 & 2511.5 \\
\hline 1997 & $2,51.80$ & 1997 & $111,384.50$ & & 111.4 & 2440.4 \\
\hline 1996 & $2,470.60$ & 1996 & $95,470.10$ & & 95.5 & 2375.1 \\
\hline 1995 & $2,400.10$ & 1995 & $81,707.30$ & & 81.7 & 2318.4 \\
\hline 1994 & $2,298.60$ & 1994 & $70,037.30$ & & 70 & 2228.6 \\
\hline 1993 & $2,208.10$ & 1993 & $83,537 \cdot 10$ & & 83.5 & 2124.6 \\
\hline 1992 & $2,150.50$ & 1992 & $72,590.40$ & & 72.6 & 2077.9 \\
\hline 1991 & $2,035.70$ & 1991 & $68,770.90$ & & 68.8 & 1966.9 \\
\hline 1990 & $1,905.20$ & 1990 & $72,205.30$ & & 72.2 & 1833 \\
\hline 1989 & $1,737.90$ & 1989 & $85,196.40$ & & 85.2 & 1652.7 \\
\hline 1988 & 1,612. 70 & 1988 & $74,312.30$ & & 74.3 & 1538.4 \\
\hline 1987 & $1,512.80$ & 1987 & $66,969.30$ & & 67 & 1445.8 \\
\hline
\end{tabular}
the covid-19 outbreak in china (Ser. Staff research report / u.s.-china economic and security review commission). U.S.-China Economic and Security Review Commission.

[6] Chinese annual GDP History. (Apr 2021). Retrieved

\begin{tabular}{|c|c|c|c|c|c|c|c|}
\hline & & & China & & US & & $\begin{array}{l}Y_{u s}-Y_{c} \\
\text { n }\end{array}$ \\
\hline $\begin{array}{l}\text { Indic } \\
\text { stors }\end{array}$ & $\begin{array}{l}100 \\
\text { million } \\
\text { RMB }\end{array}$ & $\begin{array}{l}\text { Exchang } \\
\text { e Rate }\end{array}$ & $\begin{array}{l}\text { Effective } \\
\text { Billion USD }\end{array}$ & $\begin{array}{l}\text { Grorth } \\
\text { Rate }\end{array}$ & $\begin{array}{l}\text { Billio } \\
\text { n USD }\end{array}$ & $\begin{array}{l}\text { Grouth } \\
\text { Rate }\end{array}$ & \\
\hline $\begin{array}{c}10 \\
2021\end{array}$ & $\begin{array}{r}249,310 . \\
1\end{array}$ & 6.51 & 3831. 850993 & $\begin{array}{r}-13.78 \\
\%\end{array}$ & $\begin{array}{r}5367.6 \\
87\end{array}$ & $-2.12 \%$ & $\begin{array}{r}1535.8 \\
36007\end{array}$ \\
\hline $\begin{array}{c}4 Q \\
2020\end{array}$ & $\begin{array}{r}296,297 . \\
8\end{array}$ & 6.67 & 4444. 283246 & 16. $79 \%$ & $\begin{array}{r}5484.0 \\
17\end{array}$ & $3.01 \%$ & $\begin{array}{r}1039.7 \\
33754\end{array}$ \\
\hline $\begin{array}{c}3 Q \\
2020\end{array}$ & $\begin{array}{r}264,976 . \\
3\end{array}$ & 6.96 & 3805.431593 & $8.33 \%$ & $\begin{array}{r}5323.6 \\
73\end{array}$ & $8.61 \%$ & $\begin{array}{r}1518.2 \\
41407\end{array}$ \\
\hline $\begin{array}{c}20 \\
2020\end{array}$ & $\begin{array}{r}248,985 . \\
1\end{array}$ & 7.09 & 3512. 804416 & 10. $75 \%$ & $\begin{array}{r}4901.7 \\
84\end{array}$ & $-6.55 \%$ & $\begin{array}{r}1388.9 \\
79584\end{array}$ \\
\hline $\begin{array}{c}10 \\
2020\end{array}$ & $\begin{array}{r}205,727 . \\
0\end{array}$ & 6.49 & 3171.875639 & $\begin{array}{r}-19.09 \\
\%\end{array}$ & $\begin{array}{r}5245.5 \\
2\end{array}$ & $-5.12 \%$ & $\begin{array}{r}2073.6 \\
44361\end{array}$ \\
\hline $\begin{array}{c}4 Q \\
2019\end{array}$ & $\begin{array}{r}276,798 . \\
0\end{array}$ & 7.06 & 3920.260016 & $9.10 \%$ & $\begin{array}{r}5528.3 \\
36\end{array}$ & $2.09 \%$ & $\begin{array}{r}1608.0 \\
75984\end{array}$ \\
\hline $\begin{array}{c}30 \\
2019\end{array}$ & $\begin{array}{r}251,046 . \\
3\end{array}$ & 6.99 & 3593. 201464 & 1. $20 \%$ & $\begin{array}{r}5415.3 \\
9\end{array}$ & $1.08 \%$ & $\begin{array}{r}1822.1 \\
88536\end{array}$ \\
\hline $\begin{array}{c}2 \mathrm{Q} \\
2019\end{array}$ & $\begin{array}{r}241,502 . \\
6\end{array}$ & 6.80 & 3550.567629 & 13. $93 \%$ & $\begin{array}{r}5357.3 \\
42\end{array}$ & $4.39 \%$ & $\begin{array}{r}1806.7 \\
74371\end{array}$ \\
\hline $\begin{array}{c}10 \\
2019\end{array}$ & $\begin{array}{r}217,168 . \\
3\end{array}$ & 6.97 & 3116. 558943 & $\begin{array}{r}-16.75 \\
\%\end{array}$ & $\begin{array}{r}5132.1 \\
6\end{array}$ & $-3.27 \%$ & $\begin{array}{r}2015.6 \\
01057\end{array}$ \\
\hline $\begin{array}{c}4 Q \\
2018\end{array}$ & $\begin{array}{r}258,808 . \\
9\end{array}$ & 6.91 & 3743. 523773 & $7.99 \%$ & $\begin{array}{r}5305.5 \\
54\end{array}$ & $1.65 \%$ & $\begin{array}{r}1562.0 \\
30227\end{array}$ \\
\hline $\begin{array}{c}3 Q \\
2018\end{array}$ & $\begin{array}{r}234,474 . \\
3\end{array}$ & 6.76 & 3466. 599216 & $-1.66 \%$ & $\begin{array}{r}5219.5 \\
46\end{array}$ & 1. $26 \%$ & $\begin{array}{r}1752.9 \\
46784\end{array}$ \\
\hline $\begin{array}{c}2 \mathrm{Q} \\
2018\end{array}$ & $\begin{array}{r}223,962 . \\
2\end{array}$ & 6.35 & 3525.022962 & 18. $19 \%$ & $\begin{array}{r}5154.6 \\
03\end{array}$ & 4. $51 \%$ & $\begin{array}{r}1629.5 \\
80038\end{array}$ \\
\hline $\begin{array}{c}10 \\
2018\end{array}$ & $\begin{array}{r}202,035 . \\
7\end{array}$ & 6.77 & 2982. 585844 & $\begin{array}{r}-16.14 \\
\%\end{array}$ & $\begin{array}{r}4932.1 \\
59\end{array}$ & $-2.51 \%$ & $\begin{array}{r}1949.5 \\
73156\end{array}$ \\
\hline $\begin{array}{c}4 Q \\
2017\end{array}$ & $\begin{array}{r}235,428 . \\
7\end{array}$ & 6.62 & 3556.66261 & 11. $89 \%$ & $\begin{array}{r}5059.3 \\
32\end{array}$ & $2.29 \%$ & $\begin{array}{r}1502.6 \\
6939\end{array}$ \\
\hline $\begin{array}{c}3 Q \\
2017\end{array}$ & $\begin{array}{r}212,789 . \\
3\end{array}$ & 6.69 & 3178.635448 & $8.11 \%$ & $\begin{array}{r}4946.2 \\
31\end{array}$ & 1. $51 \%$ & $\begin{array}{r}1767.5 \\
95552\end{array}$ \\
\hline $\begin{array}{c}2 \mathrm{Q} \\
2017\end{array}$ & $\begin{array}{r}201,950 . \\
3\end{array}$ & 6.87 & 2940.210233 & $3.21 \%$ & $\begin{array}{r}4872.7 \\
2\end{array}$ & $4.46 \%$ & $\begin{array}{r}1932.5 \\
09767\end{array}$ \\
\hline
\end{tabular}

\section{REFERENCES}

[1] Foot, R. (1995). The practice of power : us relations with china since 1949 . Clarendon Press.

[2] Yutao, W. (2021). Past, present, and future: Research on the Influence of International Competition and Collaboration Relationship between US and China. Journal of Finance Research.

[3] Chudik, A., Mohaddes, K., Pesaran, M. H., Raissi, M., Rebucci, A., \& National Bureau of Economic Research. (2020). A counterfactual economic analysis of covid-19 using a threshold augmented multi-country model (Ser. Nber working paper series, no. 27855). National Bureau of Economic Research.

[4] Malden, K., Stephens, S., \& U.S.-China Economic and Security Review Com

from 
https://en.wikipedia.org/wiki/Historical_GDP_of_ China

[7] Chinese Quarterly GDP History. (Apr 2021). Retrieved from https://data.stats.gov.cn/english/easyquery.htm?cn $=\mathrm{B} 01$

[8] Chinese annual government expenditure history. (Apr 2021). Retrieved from https://countryeconomy.com/government/expendit ure/china

[9] Chinese quarterly government expenditure history. (Apr 2021). Retrieved from https://data.stats.gov.cn/english/easyquery.htm?cn $=\mathrm{A} 01$

[10] Exchange rate between CNY and USD history. (Apr 2021). Retrieved from https://www.macrotrends.net/2575/us-dollar-yuanexchange-rate-historical-chart

[11] US annual government expenditure. (Apr 2021). Retrieved

from https://www.whitehouse.gov/omb/historical-tables/

[12] US quarterly government expenditure. (Apr 2021). Retrieved from https://fred.stlouisfed.org/series/NA000283Q

[13] US annual GDP History. (Apr 2021). Retrieved from https://en.wikipedia.org/wiki/Economy_of_the_Un ited_States

[14] US quarterly GDP History. (Apr 2021). Retrieved from https://fred.stlouisfed.org/series/GDP 